\title{
The use of rapid and cost-effective blood-based biomarkers in combination with tumour TNM stage for individual head and neck cancer patient treatment selection
}

\author{
Nongnit Laytragoon Lewin ${ }^{1,2}$ (1) Freddi Lewin $^{3} \cdot$ Bengt-Åke Andersson $^{1,2}$ • \\ Sture Löfgren $^{1} \cdot$ Lars Erik Rutqvist $^{4}$
}

Received: 7 February 2017/ Accepted: 28 February 2017/Published online: 18 March 2017

(C) The Author(s) 2017. This article is an open access publication

\begin{abstract}
Head and neck (H\&N) cancer is an aggressive disease and the incidence has increased in younger population worldwide. Tumour TNM staging is the main basis for treatment decision despite significant variation in clinical outcome. Survival time of these patients has marginally improved during the last 30 years. Various biomarkers with cumbersome analysis, high cost, time consumption and requirement of special laboratory facilities have been investigated. However, none of these biomarkers have been shown to be suitable to use for individual $\mathrm{H} \& \mathrm{~N}$ cancer patient treatment selection in the clinic. For practical use in clinical settings, the given biomarkers must be simple to analyse, rapid, cost effective and available in routine laboratories. With this intension, we suggested the combination of standard TNM staging and biomarkers associated with inflammation such as neutrophils, neutrophil to lymphocyte ratio, plasma C-reactive protein or plasma tumour necrosis factor alpha (TNFa) and single-nucleotide polymorphism in TNFa rs1800629 using blood-based analysis. The optimal treatment outcome of $\mathrm{H} \& \mathrm{~N}$ cancer by using combination of
\end{abstract}

Nongnit Laytragoon Lewin

nongnit.lewin@rjl.se

1 Division of Medical Diagnostic, Ryhov Hospital, 55322 Jönköping, Sweden

2 Department of Clinical and Experimental Medicine, Linköping University, 58185 Linköping, Sweden

3 Department of Oncology, Ryhov Hospital, 55322 Jönköping, Sweden

4 Swedish Match AB, 11885 Stockholm, Sweden
TNM stage and these blood-based biomarkers for individual patient selection need further investigation.

Keywords Head and neck cancer - Single-nucleotide polymorphism · Inflammation - Individualized treatment selection

\section{Introduction}

Head and neck $(\mathrm{H} \& \mathrm{~N})$ cancer is an aggressive disease and the incidence is increasing, especially in younger population worldwide [1, 2]. Relatively high loco-regional recurrent tumours, derived from local primary tumour or second primary tumour from the normal-appearing tissue were observed in these patients [3-5]. Despite aggressive and advanced treatment regimens, long-term survival in human papilloma virus (HPV) negative $\mathrm{H} \& \mathrm{~N}$ cancer is only marginally improved during the last 30 years [2, 6-12].

Tumour TNM staging is the primary guide for treatment modality despite significant heterogeneity in clinical outcome. Independent from TNM stage, number of circulating tumour cells, lymphocytes expressing cytolyses granules, neutrophils, neutrophil to lymphocyte ratio (NLR), plasma C-reactive protein (CRP), tumour necrosis factor alpha (TNFa) or downregulated $\mathrm{T}$ cell receptor Zeta chain was associated with the clinical outcome of cancer patients [13-19].

Prognostic biomarkers for individual patient treatment selection in the clinical practice need to be established for optimal clinical outcome of $\mathrm{H} \& \mathrm{~N}$ cancer patients. We emphasize the cost-effective, rapid and automatic bloodbased biomarkers in combination with TNM staging for individual treatment selection in the clinical setting of this patient group. 


\section{HPV, cigarette, alcohol, single-nucleotide polymorphism (SNP) and H\&N cancer}

Epidemiological data have established that cigarette smoking, alcohol consumption or HPV infection are the main risk factors for $\mathrm{H} \& \mathrm{~N}$ cancer [20-23]. More than $95 \%$ of these malignant tumours are squamous cell carcinoma, originating from the mucosal epithelium cells linings of the upper aero-digestive tract [24]. It is important to point out that not all HPV infected persons, heavy smokers or high alcohol consumers develop cancer. The elevated cancer risk among first-degree relatives of $\mathrm{H} \& \mathrm{~N}$ cancer patients indicated an important role of genetic factors [25, 26].

SNP is the most common source of human genetic variation in the individual germline DNA. SNP sequence variation may lead to altered effects of the gene and causes interindividual susceptibility to oncogenesis. One SNP, TNFa rs 1800629 is associated with increased risk of $H \& N$ cancer, tumour recurrence and survival time of the patients [27].

HPV is a common sexually transmitted infection and most of the sexually active women and men worldwide are infected by low-risk or high-risk HPV in their life time $[22,28,29]$. HPV infect squamous epithelial cells through cellular membrane receptors [29-31]. Sexual behaviour, oral hygiene and smoking are suggested to be related to oral HPV infection in the healthy individuals [32, 33].

High-risk HPV type might be necessary for tumorigenesis but it is not sufficient on its own [22]. Individual host SNPs influences the susceptibilities to high-risk or low-risk HPV infection process and outcome of the infection [33]. Generally, virus infected cells will carry virus genome in the episomal form, maintained at constant copy numbers and replicated along with host cellular DNA [29, 34]. Host immune response plays a role in clearance of HPV since HPV infected epithelial cells are spontaneously regressed in immunocompetent individuals [22, 35, 36].

The presence of high-risk HPV-DNA is insufficient to classify accurately tumours as an HPV associated since it might be present as the passenger, inactive virus and not the cause of malignancy $[37,38]$. The oncogenesis of highrisk HPV is suggested to occur from integrated high-risk HPV-DNA in the host DNA [36]. This high-risk, integrated HPV-DNA acquires the capacity to inhibit cellular differentiation and actively transcribes high-risk HPV oncoproteins in host cells $[39,40]$.

Two techniques, PCR and in situ hybridization (ISH), are generally used for diagnosis of high-risk HPV status in biopsy material. The presence of high-risk HPV-DNA shown by PCR or ISH is, however, insufficient to accurately classify tumours as HPV associated. Fluorescence in situ hybridization (FISH) could identify whether the high-risk HPV is oncogenic with integrated HPV-DNA or inactive with episomal HPV-DNA in the infected cells [40]. This analysis is, however, not suitable in clinical practice due to time consumption, high cost and requirement of special laboratory facilities.

Cigarette smoking and alcohol consumption are independent risk factors but when combined a synergistic effects is observed [20]. In vitro, combination of smoke extract and alcohol induces massive normal cell death and this is associated with SNP genotype of the individual donors [41, 42]. High frequency of HPV infection in multiple dysplastic lesions of smokers or alcohol users were detected [43-46]. An additive impact of SNPs, HPV, smoking and alcohol consumption on risk to develop H\&N cancer could be expected [45-48].

\section{Inflammation, SNPs and clinical outcome of $H \& N$ cancer patients}

Systemic inflammation from smoking induces massive cell death in the body might indicate by increasing circulating neutrophil, NLR, perforin expression in T cells and plasma CRP or TNFa levels were detected in healthy smokers (Luetragoon et al., manuscript in preparation). HPV infection and alcohol consumption could also increase normal cell death $[22,41,42,49]$. Independent from etiological point of view, cell death will release autologous antigens that provoke local and systemic host immune response [33]. Longterm exposures to these autologous antigens will upregulated inflammatory biomarkers, and this seems to be correlated with specific SNP sequence and not random events [26, 47].

Human solid tumours are generally infiltrated by inflammatory cells and considered to be a host attempt at the detection of emerging tumour cells and their elimination [50]. H\&N tumours are among the most highly immune-infiltrated cancer types. The smoking patient with tumours harbouring mutation signatures and lower immune infiltration had a shorter survival time [51, 52].

Elevated frequency and enhanced suppression capacity of regulatory T cells (Treg) was detected in blood circulation of $H \& N$ cancer patients $[53,54]$. Increased levels of circulating plasma CRP and TNFa was associated with survival of $\mathrm{H} \& \mathrm{~N}$ cancer patient $[15-17,27]$. Thus, tumour and the inflammatory cells might acquire the immunosuppressive activity or secretion inflammatory cytokines $[55,56]$.

\section{Blood-based genetic and inflammation biomarkers in $H \& N$ cancer patients}

Peripheral blood contains immune response cells, plasma proteins, cytokines and variable mediators with wideranging biologic effects. Circulating blood are in direct 
contact with all organs, non-invasive to obtain and suitable for transportation. Analysis of SNPs and inflammatory biomarkers could be simply done using this peripheral blood sample.

Using only TNM stage as treatment selection might be practical but not optimal to predict clinical outcome of $\mathrm{H} \& \mathrm{~N}$ cancer patients. Independent from tumour etiological or TNM stage, SNP in TNFa and elevating number of inflammatory biomarkers obtained from pre-treatment peripheral blood sample is associated with the clinical outcome of $\mathrm{H} \& \mathrm{~N}$ cancer patients [7, 15-17, 27]. Analysis of SNPs and these inflammation biomarkers using peripheral blood samples are well established. They are rapid, cost effective and can be done with automatic equipment, existing in the routine laboratory.

With intension to be used as biomarkers in clinical practice, such analysis must be rapid, available in routine laboratory facility and cost effective. For optimal personalized H\&N cancer treatment, we propose the pre-treatment blood-based biomarkers with focus on TNFa rs1800629, neutrophil counts, NLR, plasma CRP and TNFa in combination with standard pathological diagnosis and TNM classification for individual H\&N cancer patient treatment selection. The prognostic value of this combination warrants future clinical investigation.

\section{Conclusion}

The impact of genetic variation, smoking, alcohol consumption, HPV infection and HPV integration significantly influence host immune response [22, 23, 31, 42, 52]. This could facilitate the formation of an inflammation microenvironment and systemic inflammation that favours carcinogenesis and cancer progression in $\mathrm{H} \& \mathrm{~N}$ cancer patients $[15,17,23,27]$. The clinical significance of SNPs and systemic inflammatory biomarkers investigated at the diagnostic time, suggests the possibility of individual patient treatment selection [7, 15, 16, 18, 27].

The analysis of TNFa rs1800629 and systemic inflammatory biomarkers such as plasma CRP, TNFa or neutrophil and NLR using blood sample are rapid, cost effective and require only common facility in the routine laboratory. Thus, blood-based biomarkers offer an attractive possibility to use in combination with standard tumour TNM stage for individual H\&N cancer patient treatment selection in the clinical setting. The prognostic value of TNM stage combined with these blood-based biomarkers for treatment selection of $\mathrm{H} \& \mathrm{~N}$ cancer patients warrants further investigation.

Acknowledgements We would like to thank Thitiya Luetragoon for healthy smokers results. This review was supported by Jönköping
Clinical Cancer Research Foundation (Grant 110426-1), Futurum (Grant 144631), Medical Research Council of Southern Sweden (FORSS, Grant 567001) Office of Science \& Technology in Brussels, Ministry of Science \& Technology, Research and researchers for industries foundation (Grant PHD 6010017), Thailand and the Swedish Laryngeal Foundation. The funders had no role in the study design, data collection, analysis and interpretation of the manuscript or decision to submit the article for publication.

\section{Compliance with ethical standards}

Conflict of interest All authors declare no potential conflict of interest.

Human and animal rights This article was the literature review without human or animal involved.

Open Access This article is distributed under the terms of the Creative Commons Attribution 4.0 International License (http://creative commons.org/licenses/by/4.0/), which permits unrestricted use, distribution, and reproduction in any medium, provided you give appropriate credit to the original author(s) and the source, provide a link to the Creative Commons license, and indicate if changes were made.

\section{References}

1. Ferlay J, Shin HR, Bray F, Forman D, Mathers C, Parkin DM. Estimates of worldwide burden of cancer in 2008: GLOBOCAN 2008. Int J Cancer. 2010;127(12):2893-917.

2. Forastiere A, Koch W, Trotti A, Sidransky D. Head and neck cancer. N Engl J Med. 2001;345(26):1890-900.

3. Laytragoon-Lewin N, Chen F, Castro J, Elmberger G, Rutqvist LE, Lewin F, et al. DNA content and methylation of p16, DAPK and RASSF1A gene in tumour and distant, normal mucosal tissue of head and neck squamous cell carcinoma patients. Anticancer Res. 2010;30(11):4643-8.

4. Supic G, Kozomara R, Jovic N, Zeljic K, Magic Z. Prognostic significance of tumor-related genes hypermethylation detected in cancer-free surgical margins of oral squamous cell carcinomas. Oral Oncol. 2011;47(8):702-8.

5. Do KA, Johnson MM, Lee JJ, Wu XF, Dong Q, Hong WK, et al. Longitudinal study of smoking patterns in relation to the development of smoking-related secondary primary tumors in patients with upper aerodigestive tract malignancies. Cancer. 2004;101(12):2837-42.

6. Yoshitake Y, Fukuma D, Yuno A, Hirayama M, Nakayama H, Tanaka T, et al. Phase II clinical trial of multiple peptide vaccination for advanced head and neck cancer patients revealed induction of immune responses and improved OS. Clin Cancer Res. 2015;21(2):312-21.

7. Peter F, Wittekindt C, Finkensieper M, Kiehntopf M, GuntinasLichius O. Prognostic impact of pretherapeutic laboratory values in head and neck cancer patients. J Cancer Res Clin Oncol. 2013;139(1):171-8.

8. Mockelmann N, Laban S, Pantel K, Knecht R. Circulating tumor cells in head and neck cancer: clinical impact in diagnosis and follow-up. Eur Arch Otorhinolaryngol. 2014;271(1):15-21.

9. Siu LL, Waldron JN, Chen BE, Winquist E, Wright JR, Nabid A, et al. Effect of standard radiotherapy with cisplatin vs accelerated radiotherapy with panitumumab in locoregionally advanced squamous cell head and neck carcinoma: a randomized clinical trial. JAMA Oncol. 2017;3(2):220-6.

10. Mellin H, Friesland S, Lewensohn R, Dalianis T, Munck-Wikland E. Human papillomavirus (HPV) DNA in tonsillar cancer: 
clinical correlates, risk of relapse, and survival. Int $\mathrm{J}$ Cancer. 2000;89(3):300-4.

11. Friesland S, Mellin H, Munck-Wikland E, Nilsson A, Lindholm J, Dalianis $\mathrm{T}$, et al. Human papilloma virus (HPV) and p53 immunostaining in advanced tonsillar carcinoma-relation to radiotherapy response and survival. Anticancer Res. 2001; 21(1B):529-34.

12. Fakhry C, Westra WH, Li S, Cmelak A, Ridge JA, Pinto H, et al. Improved survival of patients with human papillomavirus-positive head and neck squamous cell carcinoma in a prospective clinical trial. J Natl Cancer Inst. 2008;100(4):261-9.

13. Laytragoon-Lewin N, Porwit-MacDonald A, Mellstedt H, Lewin F. Alteration of cellular mediated cytotoxicity, T cell receptor zeta (TcR zeta) and apoptosis related gene expression in nasopharyngeal carcinoma (NPC) patients: possible clinical relevance. Anticancer Res. 2000;20(2B):1093-100.

14. Laytragoon-Lewin N, Jonson F, Lundgren J, Rutqvist LE, Wikby A, Lofgren S, et al. Perforin, CD28 and CD95 expression in circulating CD4 and CD8 cells as predictors of head and neck $(H \& N)$ cancer patient survival. Med Oncol. 2014;31(12):290.

15. Andersson BA, Lewin F, Lundgren J, Nilsson M, Rutqvist LE, Lofgren $\mathrm{S}$, et al. Plasma tumor necrosis factor-alpha and C-reactive protein as biomarker for survival in head and neck squamous cell carcinoma. J Cancer Res Clin Oncol. 2014;140(3):515-9.

16. Valero C, Pardo L, Lopez M, Garcia J, Camacho M, Quer M, et al. Pretreatment count of peripheral neutrophils, monocytes, and lymphocytes as independent prognostic factor in patients with head and neck cancer. Head Neck. 2017;39(2):219-26.

17. Charles KA, Harris BD, Haddad CR, Clarke SJ, Guminski A, Stevens M, et al. Systemic inflammation is an independent predictive marker of clinical outcomes in mucosal squamous cell carcinoma of the head and neck in oropharyngeal and nonoropharyngeal patients. BMC Cancer. 2016;16:124.

18. Wang Z, Cui K, Xue Y, Tong F, Li S. Prognostic value of circulating tumor cells in patients with squamous cell carcinoma of the head and neck: a systematic review and meta-analysis. Med Oncol. 2015;32(5):164.

19. Wu X, Mastronicola R, Tu Q, Faure GC, De Carvalho Bittencourt M, Dolivet G. A rare case of extremely high counts of circulating tumor cells detected in a patient with an oral squamous cell carcinoma. BMC Cancer. 2016;16:552.

20. Lewin F, Norell SE, Johansson H, Gustavsson P, Wennerberg J, Biorklund A, et al. Smoking tobacco, oral snuff, and alcohol in the etiology of squamous cell carcinoma of the head and neck: a population-based case-referent study in Sweden. Cancer. 1998;82(7):1367-75.

21. Westra WH. The changing face of head and neck cancer in the 21st century: the impact of HPV on the epidemiology and pathology of oral cancer. Head Neck Pathol. 2009;3(1):78-81.

22. zur Hausen H. Papillomaviruses and cancer: from basic studies to clinical application. Nat Rev Cancer. 2002;2(5):342-50.

23. Lefevre M, Rousseau A, Rayon T, Dalstein V, Clavel C, BebyDefaux A, et al. Epithelial to mesenchymal transition and HPV infection in squamous cell oropharyngeal carcinomas: the papillophar study. Br J Cancer. 2017;116(3):362-9.

24. Chaturvedi AK, Anderson WF, Lortet-Tieulent J, Curado MP, Ferlay J, Franceschi S, et al. Worldwide trends in incidence rates for oral cavity and oropharyngeal cancers. J Clin Oncol. 2013;31(36):4550-9.

25. Foulkes WD, Brunet JS, Sieh W, Black MJ, Shenouda G, Narod SA. Familial risks of squamous cell carcinoma of the head and neck: retrospective case-control study. BMJ. 1996;313(7059): 716-21.

26. Yen CY, Liu SY, Chen $\mathrm{CH}$, Tseng HF, Chuang LY, Yang $\mathrm{CH}$, et al. Combinational polymorphisms of four DNA repair genes $\mathrm{XRCC} 1, \mathrm{XRCC} 2, \mathrm{XRCC} 3$, and XRCC4 and their association with oral cancer in Taiwan. J Oral Pathol Med. 2008;37(5):271-7.

27. Laytragoon-Lewin N, Cederblad L, Andersson BA, Olin M, Nilsson M, Rutqvist LE, et al. Single-nucleotide polymorphisms and cancer risk, tumor recurrence, or survival of head and neck cancer patients. Oncology 2017;92:161-9.

28. Frazer IH, Leggatt GR, Mattarollo SR. Prevention and treatment of papillomavirus-related cancers through immunization. Annu Rev Immunol. 2011;29:111-38.

29. Langsfeld E, Laimins LA. Human papillomaviruses: research priorities for the next decade. Trends Cancer. 2016;2(5):234-40.

30. Hummel M, Hudson JB, Laimins LA. Differentiation-induced and constitutive transcription of human papillomavirus type $31 \mathrm{~b}$ in cell lines containing viral episomes. J Virol. 1992;66(10): 6070-80.

31. Zou J, Cao Z, Zhang J, Chen T, Yang S, Huang Y, et al. Variants in human papillomavirus receptor and associated genes are associated with type-specific HPV infection and lesion progression of the cervix. Oncotarget. 2016;7(26):40135-47.

32. Herrero R, Castellsague X, Pawlita M, Lissowska J, Kee F, Balaram P, et al. Human papillomavirus and oral cancer: the International Agency for Research on Cancer multicenter study. J Natl Cancer Inst. 2003;95(23):1772-83.

33. Shigeishi H, Sugiyama M. Risk factors for oral human papillomavirus infection in healthy individuals: a systematic review and meta-analysis. J Clin Med Res. 2016;8(10):721-9.

34. zur Hausen $\mathrm{H}$. The search for infectious causes of human cancers: where and why. Virology. 2009;392(1):1-10.

35. Conesa-Zamora P. Immune responses against virus and tumor in cervical carcinogenesis: treatment strategies for avoiding the HPV-induced immune escape. Gynecol Oncol. 2013;131(2): $480-8$.

36. zur Hausen H. Papillomaviruses in the causation of human cancers-a brief historical account. Virology. 2009;384(2):260-5.

37. Gronhoj Larsen C, Gyldenlove M, Jensen DH, Therkildsen MH, Kiss K, Norrild B, et al. Correlation between human papillomavirus and p16 overexpression in oropharyngeal tumours: a systematic review. Br J Cancer. 2014;110(6):1587-94.

38. Mehanna H, Beech T, Nicholson T, El-Hariry I, McConkey C, Paleri V, et al. Prevalence of human papillomavirus in oropharyngeal and nonoropharyngeal head and neck cancer-systematic review and meta-analysis of trends by time and region. Head Neck. 2013;35(5):747-55.

39. Kim SH, Koo BS, Kang S, Park K, Kim H, Lee KR, et al. HPV integration begins in the tonsillar crypt and leads to the alteration of p16, EGFR and c-myc during tumor formation. Int J Cancer. 2007;120(7):1418-25.

40. Hafkamp HC, Speel EJ, Haesevoets A, Bot FJ, Dinjens WN, Ramaekers FC, et al. A subset of head and neck squamous cell carcinomas exhibits integration of HPV 16/18 DNA and overexpression of p16INK4A and p53 in the absence of mutations in p53 exons 5-8. Int J Cancer. 2003;107(3):394-400.

41. Laytragoon-Lewin N, Bahram F, Rutqvist LE, Turesson I, Lewin F. Direct effects of pure nicotine, cigarette smoke extract, Swedish-type smokeless tobacco (Snus) extract and ethanol on human normal endothelial cells and fibroblasts. Anticancer Res. 2011;31(5):1527-34.

42. Cederblad L, Thunberg U, Engstrom M, Castro J, Rutqvist LE, Laytragoon-Lewin $\mathrm{N}$. The combined effects of single-nucleotide polymorphisms, tobacco products, and ethanol on normal resting blood mononuclear cells. Nicotine Tob Res. 2013;15(5):890-5.

43. Tinhofer I, Johrens K, Keilholz U, Kaufmann A, Lehmann A, Weichert W, et al. Contribution of human papilloma virus to the incidence of squamous cell carcinoma of the head and neck in a European population with high smoking prevalence. Eur J Cancer. 2015;51(4):514-21. 
44. Tsai CW, Chang WS, Gong CL, Shih LC, Chen LY, Lin EY, et al. Contribution of matrix metallopeptidase-1 genotypes, smoking, alcohol drinking and areca chewing to nasopharyngeal carcinoma susceptibility. Anticancer Res. 2016;36(7):3335-40.

45. Katada C, Yokoyama T, Yano T, Kaneko K, Oda I, Shimizu Y, et al. Alcohol consumption and multiple dysplastic lesions increase risk of squamous cell carcinoma in the esophagus, head, and neck. Gastroenterology. 2016;151(5):860-869 e7.

46. Heijink IH, Pouwels SD, Leijendekker C, de Bruin HG, Zijlstra GJ, van der Vaart $\mathrm{H}$, et al. Cigarette smoke-induced damageassociated molecular pattern release from necrotic neutrophils triggers proinflammatory mediator release. Am J Respir Cell Mol Biol. 2015;52(5):554-62.

47. Pouwels SD, Heijink IH, Brouwer U, Gras R, den Boef LE, Boezen HM, et al. Genetic variation associates with susceptibility for cigarette smoke-induced neutrophilia in mice. Am J Physiol Lung Cell Mol Physiol. 2015;308(7):L693-709.

48. Chaturvedi AK, D'Souza G, Gillison ML, Katki HA. Burden of HPV-positive oropharynx cancers among ever and never smokers in the U.S. population. Oral Oncol. 2016;60:61-7.

49. Doorbar J, Quint W, Banks L, Bravo IG, Stoler M, Broker TR, et al. The biology and life-cycle of human papillomaviruses. Vaccine. 2012;30(Suppl 5):F55-70.
50. Whiteside TL. The tumor microenvironment and its role in promoting tumor growth. Oncogene. 2008;27(45):5904-12.

51. Bindea G, Mlecnik B, Tosolini M, Kirilovsky A, Waldner M, Obenauf AC, et al. Spatiotemporal dynamics of intratumoral immune cells reveal the immune landscape in human cancer. Immunity. 2013;39(4):782-95.

52. Mandal R, Senbabaoglu Y, Desrichard A, Havel JJ, Dalin MG, Riaz $\mathrm{N}$, et al. The head and neck cancer immune landscape and its immunotherapeutic implications. JCI Insight. 2016;1(17):e89829.

53. Strauss L, Bergmann C, Gooding W, Johnson JT, Whiteside TL. The frequency and suppressor function of CD4+ CD25highFox$\mathrm{p} 3+\mathrm{T}$ cells in the circulation of patients with squamous cell carcinoma of the head and neck. Clin Cancer Res. 2007;13(21): 6301-11.

54. Lou H, Fang J, Li P, Zhou W, Wang Y, Fan E, et al. Frequency, suppressive capacity, recruitment and induction mechanisms of regulatory $\mathrm{T}$ cells in sinonasal squamous cell carcinoma and nasal inverted papilloma. PLoS ONE. 2015;10(5):e0126463.

55. Serafini P, Borrello I, Bronte V. Myeloid suppressor cells in cancer: recruitment, phenotype, properties, and mechanisms of immune suppression. Semin Cancer Biol. 2006;16(1):53-65.

56. Balkwill F, Coussens LM. Cancer: an inflammatory link. Nature. 2004;431(7007):405-6. 